\title{
ARCHIVING COLLECTIVE MEMORIES AND (DIS)OWNING
}

\author{
Rémi Armand Tchokothe \\ University of Bayreuth, Germany
}

\begin{abstract}
This paper investigates the question of ownership of collective memories in the age of digitized archiving. The United Nations Educational, Scientific and Cultural Organization's (henceforth Unesco) philosophy of preserving the world cultural heritage has boosted research on African oral literatures. The emphasis on the documentation of endangered cultures of Africa is salutary but also raises some critical questions. The central question this contribution addresses is that of the authorship-ownership of cultural heritage that is being archived in the framework of digital humanities. In essence, the notion of "collective memories" entails that of collective authorship and collective belonging as these memories are passed on from one generation to the other without the claim of singular ownership. A significant example in this line of thought has been the observation by the cultural giant Amadou Hampâté Bâ who ironically pointed out that the real author of The Fortunes of Wangrin (1973), which is attributed to him, is actually the storyteller Wangrin - the cunning interpreter - and members of the whole literary tradition that Wangrin embodied. In the preface of a recently published volume on La question de l'auteur en littératures africaines (Jérôme Roger 2015: 16) the author asks the following pertinent question: how can African literature, both oral and others, invite scholars to rethink the relationship between the anonymity of sources, versions and variants of stories and the constraint for an author's name imposed by editors? The question has more weight in view of the massive digitization of African oral literatures that mostly takes place in institutions with more economic prestige and which are located outside the African continent. Therefore, the interrogation centres on the role of power with regard to the form in which these (hi)stories are published, where, how and to whom they are accessible, and to the habit of researchers to name people from whom they receive the bulk of knowledge which they transcribe and translate into the academic jargon "informants" instead of giving them more credit by referring to them as research partners or even by recognising them as co-authors. In this vein, the paper rounds up by exploring the possibility of reversing the customary auctorial perspective by bringing into the discussion the idea of "researchers as griots" suggested by (Merolla, Ameka \& Dorvlo 2013).
\end{abstract}

KEYWORDS: ARCHIVING AND SILENCING, MEMORICIDE, TEACHERS ON THE FIELD, SELFISH ALTRUISM, RESEARCHERS AS GRIOTS

\section{Technauriture and (Dis)owning}

This position paper addresses the question of (dis) ownership of collective memories in the age of archiving through hyper-mediated digitization and the current phenomenon of massive and rapid mobility which (Kros 2015: 694) calls "hypertravel". The choice of the word (dis) ownership is explained by the ambiguity surrounding numerous projects on the documentation and archiving of collective and cultural knowledge from communities on the African continent when it comes to the question of ownership of the knowledge that later materializes in the form of articles, books, audio compact cassettes, audio com- 
pact discs, video compact discs, secure digital memory cards, online archives, encyclopedia etc. I follow (Hamilton 2010: unpublished paper) who sees the archive as a 'repository of information ... a site where the politics of knowledge emerges'.

Oral literature or "technauriture" is a genre through which the politics of knowledge is best at play. Technauriture "describes how technology, auriture and literature intersect to transmit education and other messages within" (Kaschula 2017: 41). Technauriture sees oral literature as being under the prism of globalisation characterized by technology which changes at a tremendous speed. I would argue that there is a link between technauriture and the problem of (dis) owning since the technologisation of African oral literatures goes hand in hand with the power to have the necessary technology or means to acquire the technological equipment; which mostly remain the privilege of countries of the North.

Another reason that speaks for oral literature as the genre per se to investigate the politics of knowledge construction, legitimation and de-legitimation is its quintessentially multidisciplinary nature. In the words of (Aggarwal 1999: 206):

Oral tradition is the great school of life; it deals with religion, natural sciences as well as with the knowledge of minerals, of pharmacopoeia and medicine, of professional initiation, of history, of games and leisure, of love and death. Knowledge, in African oral societies, is concerned with the practical behavior of man in his group. It is not abstract and cut off from life, but rather bound to the present life and to the origin of all knowledge, through the word of God. (Translation by Moura 2006: 93).

\section{Empowering not Disempowering}

Research on oral literatures is therefore a work on the total sum of what makes a Community; to be specific, it is a work on who the people are, the constituency of their being, all elements that render this constituency viable and therefore a research on what actually belongs to given communities. The Unesco's philosophy of preserving the world cultural heritage has pushed the number of research projects on African oral literatures, African cultures, African textures and even African contextures (literatures, music, dance, arts etc). This increase in the documentation of some endangered cultures in analogy to endangered languages of Africa deserves acknowledgement even though it raises a number of questions amongst which is the authorship-ownership of the cultural heritage that is being archived in the framework of digital humanities.

The central question this paper wants to ask is the following: how can one research the oral literatures or the cultures of a people while ensuring that they will not be dispossessed of their knowledge and copyrights ${ }^{1}$ about this knowledge that is a cultural heritage?

The notion of "collective memories" entails that of "collective authorship" or "auctorial plurality"; an expression on which (Meizoz 2007) insists for literary works. To Meizoz, literature is as an activity which involves many agents such as authors, editors, book de-

1 Jansen (2012) has taken the debate a step further by talking about the "copy debts" of the researchers towards the communities. 
signers, readers, critics, translators, bookshops and libraries, literary institutions, media, etc. These 'professional valuers' to use Bourdieu's (1992) concept, recur to their cultural, social or economic capital to shape the production, circulation, and reception of literary works.

\section{"The Text is the product of a dead man"}

Regarding oral literature, an observation in this line of thought was made by the cultural giant Hampaté Bâ from Mali who ironically pointed out that the real author of The Fortunes of Wangrin (2000) that is attributed to him following common editorial practices is actually the storyteller - the storyowner or the community griot Wangrin together with all members of the Fula oral tradition of Mali from whom he received the knowledge. To (Moura 2006: 91)

L'étrange destin de Wangrin (The Fortunes of Wangrin), published in 1973 by the Malian scholar Amadou Hampate Ba, is a textbook case for a volume of essays devoted to the question of "textual ownership." From the beginning of the book, Hampate $\mathrm{Ba}$ informs the reader that he is not the author and that the text is the product of a dead man named Wangrin who told him the story. A long time after Wangrin's death, Hampate Ba simply transcribed his words as he remembered them.

Moura attempts to take the debate on authorship a step further, but the result is confusing because upon downloading the paper from which the quotation originates one is happily surprised to read the following: "Author(s): Jean-Marc Moura and Amadou Hampaté Bâ" but as soon as one scrolls through the text only the name Jean-Marc Moura is assigned to the text. This shows that the question of authorship is not an easy one to deal with especially when it comes to information and material that are acquired in one cultural context and is validated as knowledge and circulates in a totally different context.

In the preface of a recent volume on La question de l'auteur en littératures africaines (2015), (Jérôme Roger 2015: 16) asks the pertinent question: how can African literature, both oral and others, invite scholars to rethink the relationship between the anonymity of sources, versions and variants of stories and the constraint for an author's name imposed by editors? The question has more weight in view of massive digitization of African oral literatures that mostly takes place in institutions with more economic prestige and which are located outside the African continent. One could mention the examples of the World Oral Literature Project at the University of Cambridge and the Documentation of Endangered Languages (DOBES) graciously sponsored by the VolkswagenStiftung which both used innovative research approaches and which have produced impressive and sustainable results, but they could not fully solve problems of ownership of data, the naming of participants in the research process and access to the archived data.

Therefore, the concern of this paper correlates to the role of symbolic power (Bourdieu, 2003) with regard to the form in which these (hi)stories are published, where, how and 
to whom they are accessible ${ }^{2}$ and to the still common naming practice in the academia. Following Bourdieu, the Nomos can be used to legitimize but also to de-legitimize. Thus, naming can be tactful battles over power hierarchies in the academic field, which leads to the issue of owning and /or disowning. A testimony to this point is the fact that researchers in the broad field of African Studies name thereby legitimating or de-legitimating the people from whom they receive the bulk of knowledge that they transcribe and translate into the academic jargon 'informants', 'researched', 'research object' or progressively 'consultants' as it is the case with the Documentation of Endangered Languages. In doing so, they confine these people to passive actors who mainly deliver information that is later 'transformed - sophisticated' into knowledge which is later inscribed and sacralised in so-called "learned" circles.

\section{Teachers in the field, Co-authors}

What I would like to suggest here is to break away from the common paradigm by focusing on the adjective, namely to see these people not as "informants" 3 ", a word that at the onset is semantically ambiguous. I would rather suggest seeing the people as "informed", meaning putting the emphasis on people who are resourceful, knowledgeable and literally knowledge able, people in the picture and even experts who participate in a cooperative narrative. Actually the verb "inform" implies the agency of people who help and even teach researchers to form their opinion on given topics. Therefore, the paper pleads for an epistemic delinking ${ }^{4}$ and an epistemic interculturality along the lines of the "grammar of decoloniality" introduced by the Argentinian (Walter Mignolo 2010: 352) who asks a basic question: is the West all over the rest or is the rest all over the West? To (Mignolo (2010: 346)

The grammar of de-coloniality (e.g., de-colonization of knowledge and of being and consequently of political theory and political economy) begins at the moment that languages and subjectivities have denied the possibility of participating in the production, distribution, and organization of knowledge. The colonization of knowledge and of being worked from top down and that is the way it is still working today: looking from economy and politics, corporations and the state down. That is the way social sciences and financial and political think thanks work [...] The grammar of de-coloniality is working, has to work, from bottom up.

A first step in de-linking and breaking away from "epistemic complicity" (Sanders, 2002) can consist in giving hitherto called "informants" the credit they deserve by institutional-

2 (Nathan 2013: 33) rightly notes that "we have to shift our focus from access to accessibility."

3 An interesting example of the contradiction inherent in this word is provided by Nfah-Abbenyi (1999). As a scholar she was invited to "speak to a class of undergraduate and graduate students on 'African' Women's Writing" " (21) only to find out that she had been referred to several times in class by "the brilliant feminist" who had invited her as "my African friend" and "the informant" instead or being appropriately named and consequently quoted as the reliable and knowledgeable source she is. 
izing them as knowledge repertoires, knowledge repositories, "knowledge communities"5, teachers in the field, "partners in a dialogue" or even to celebrate them as co-authors, which might solve some of the conflictual histories behind Africanist research practice, the issue to which I turn now.

In her excellent and very thought-provoking book titled Accented Futures. Language Activism and the Ending of Apartheid, (Carli Coetzee 2013: 7-8) defends accentedness which, to her, means "resistance to absorption" and "attitudes that challenges and defies those in power and aims to bring to the surface conflictual histories".

\section{Africanist Research Practice and Memoricide}

Conflicting histories are the issue at stake here because the current Africanist research practice does not pay enough attention to people who are the main agents of Africanist knowledge - exemplified here in endeavors to archive collective memories-. Coetzee's work is particularly innovative in two regards: it is significant for this reflection on African oral literatures, namely what she labels "there was this missing quotation mark" and "the copy and the lost original". The following quotation from (Coetzee 2013: 9-10) illustrates the issue at stake

Like many countries with violent histories of colonisation, South African life is marked by cultural and linguistic extinctions. It is the meaning of one such lost 'origin' that forms the topic of the chapter called 'The copy and the lost original' which traces the ways in which a particular set of documents and artefacts has entered academic and intellectual life: the documents and artefacts now known as the Bleek-Lloyd archive. While the memorialisation of lost cultures and languages is no doubt commendable [...] the academic and artistic pursuit of such a lost world risks placing the remembering as a new origin, thereby divesting us - the academics and intellectuals - of any complicity in the discovery and destruction.

Coetzee's observation is relevant on one other major count: the danger of archiving/memorialisation turning out to be memoricide or the erasure of the main agents. The symbolic damages of this obliteration can be read in the following

This translational scene is the relationship between a German philologist, Wilhelm Bleek, his niece, Lucy Lloyd, and a group of /Xam teacher-informants. The archive has, significantly, for my argument, come to be known as the 'Bleek/Lloyd archive', missing out the names of the teacher-informants, and only commemorating the names of the transcribers. (Coetzee, 2013:92).

5 Speaking about the rich knowledge of plants among the Adivasi of India and the need to preserve them and to convert them into profitable currency, Devy \& Brown (2010:33) warn that "it is necessary to ask if adivasis cannot be made to participate in the contemporary knowledge processes, and be seen as 'knowledge communities' of their own unique kind." Such a process would be inscribed in the decolonial approach, it will give visibility to the owners of the knowledge and would be a step ahead regarding the question of copyright which is at the heart of the transfer from orality to literacy.

6 See Lohnert (2007) and The Council for the Development of Social Research in Africa (CODESRIA) which has been arguing for the use of the word partnership. 
It is worth highlighting that in the quotation above, Coetzee introduced the idea of teachers-informants' as a category which centers on the competence of people who by oral legacy stand for the representatives of the community knowledge. These knowledgeable people should be given more space by, for example being encouraged to be part of the academic teaching system, even though they are not recognised as formally qualified in the Western sense. A pioneer in this challenging approach is the anthropologist and philosopher Professor Cheikh Niang of the University of Cheikh Anta Diop de Dakar who started inviting 'marabouts' to his classes in medical and social anthropology in order to enable discussion between these knowledgeable people with a symbolical social role and students, which has broken some myths about their work and enabled students to engage critically with non-Western complex systems of knowledge to which they have an experiential relation.

In line with Coetzee's notice, another example that caught my attention was an e-mail I received as a member of the Association pour l'Étude des Littératures Africaines on January 26, 2016. The e-mail read:

It is with great pleasure that $I$ can announce that the British Library has officially launched the Syliphone archive, a collection of nearly 8,000 songs from the archives of Radio Télévision Guinée. The songs are now available to listen to online at the British Library Sounds website [...]. The recordings were archived between 20082013 with Endangered Archives Programme funding, and the collection contains the finest recordings made in Guinea. The songs date from 1960, with the bulk recorded during the era of Guinea's $1^{\text {st }}$ Republic (1958-1984). The songs archived from reel-to-reel magnetic tape (7000+ songs) include Guinea's most famous artists and contains their complete catalogues. Much of this material has never been broadcast outside of Guinea. A (brief) list of these artists includes [...] all of the national orchestras. All of the 35 regional orchestras. Hundreds of recordings by choirs, ensembles and ballets. Hundreds of recordings by Guinean stars. Hundreds of recordings by artists and groups of the post-Sékou Touré era. Hundreds of recordings of traditional ensembles. For further information on the archive see my blog at the British Library website and my website: Radio Africa. Happy listening! (Graeme 2016)

I spent hours trying to sift through this immense and highly admirable initiative but I could not stop asking myself the question: what about Guineans who actually own this cultural heritage and those who worked with the digitizer and arranged the facilities for his work during five years? This archive unfortunately glorifies the British donor who owns the copyrights and positions an individual "selfish altruist" (to use an expression that (Vaux: 2001) critically applied to himself as a former worker for the Oxford Famine) as the heroic archivist, rendering the researcher-collector into the original author, which boils down to placing the remembering as a 'new origin' as Coetzee would say. 


\section{"If you want to dispossess a people, the simplest way to do it is to tell their story"}

As one can notice in the example above, many actors of this huge and time-consuming project have been made faceless and voiceless. The vast work of leaving traces of these records which was completed by the most visible person in the process deserves much credit, as testified by the fact that "in recognition of his research and contribution to the preservation of national culture, the Guinean government awarded the scholar their highest research honour, the gold medal of the Palme Académique en or and a Diplôme d'Honneur" (http://findanexpert.unimelb.edu.au/display/person183008).

Nonetheless, one would have wished that the learner-collector who uses the first person narrative as highlighted in the announcement had not fully appropriated the stories at the moment to put them online, which reminds of the words of the Palestinian poet Mourid Barghouti "If you want to dispossess a people, the simplest way to do it is to tell their story" (qtd. in Adichie 3). In this insightful talk whose transcript I refer to here, Chimamanda Adichie talks with great wit about "the danger of a single story" which characterizes essentialist discourses about Africa especially from the Western perspective. In this example, the paternalising/institutional appropriation of thousands of stories in the framework of a project that was well intended illustrates the recurrent issue of power which is central to Africanist research practices. In Adichie's (ibid.) words

It is impossible to talk about the single story without talking about power. There is a word, an Igbo word, that I think about whenever I think about the power structures of the world, and it is "nkali". It's a noun that loosely translates to "to be greater than another". Like our economic and political worlds, stories too are defined by the principle of nkali. How they are told, who tells them, when they're told, how many stories are told, are really dependent on power.

The idea to make the huge amount of accumulated knowledge available online and claiming ownership over it brings about mixed feelings because the results celebrate the visibility of one person and the institution the person embodies, while major inheritors of the knowledge and major participants in the process of making this knowledge sustainable are rendered invisible. One wishes that the most visible protagonist in this case had followed what another learner on the field did in the framework of a project also sponsored by the Endangered Archives Programme, namely the archive collection of the Photographic Information Service in Buea.

This collection contains images documenting "all the official ceremonies and things of general interest" taking place in the Anglophone part of Cameroon between 1955 and 1980. Here, Pa Mbwaye born 1928, the Photographic Information Service's first photographer who retired 33 years ago is praised publicly as the "living archive". It is not accidental that the series "Beacons of time" of the Cameroon Radio and Television (CRTV) dedicated a documentary to Pa Mbwaye in 2013.

Another case of getting major faces involved in the knowledge preservation and the knowledge production process visible is that of Jeff Opland's series on early IsiXhosa writers published by the University of Kwa Zulu Natal Press in which the original au- 
thors such as Nontsizi Mgqwetho, SEK Mqhayi, John Solilo, William Gqoba and DLP Yali-Manisi are given their right and copyright as authors of the respective works. This practice of recognizing these texts as cooperative narratives explains why Jeff Opland was awarded the Order of Ikhamanga ${ }^{7}$ in 2017 by the South African Presidency for bringing these authors and their works to the fore.

Both counter-examples show that making principal voices and faces hearable, visible and quotable as knowledge sources is an approach which is possible in Africanist research practice on the whole, and particularly in archiving collective memories which requires utmost sensitivity to the data, sensitivity about research ethics and genuine respect for the people who trust us, dedicate their time to us, teach us patiently, care for us during field research, and entrust us with immense knowledge of their cultures and peoples. This approach requires "researchers" to be humble enough to interrogate their own "positionality" before the field research, during the field research, after the research stay and especially at the moment of publishing research results. I now turn to the last aspect in which positionality is central: researchers as griots.

\section{Researchers as Griots}

This contribution sees the need to bring into the discussion the idea of 'researchers as griots' and researchers as "animators or editors who shape and polish, embellish, and retouch offensive language in more palatable language and communicate it through the medium of Verba Africana to the outside world: the addressees" (Merolla, Ameka, \& Dorvlo 2013: 84). The implication for researchers is to reverse the perspective by looking at themselves as people at the service of the communities they are working on and with and not viewing the communities as being at their service. This goes together with the question of what should be at the heart of the discussion: is it the people, the knowledge or the channels through which knowledge that is essentially taken out of its primary context circulates?

A genuine answer to this question was provided by the series Publications of the Opland Collection of Xhosa Literature in which Opland, Kuse \& Maseko (2015) for example, restituted the original authorship of Isizwe esinembali. Xhosa histories and poetry (18731888) to William Wellington Gqoba and despite their respective academic ranks presented themselves as editors and translators of the works of Gqoba who they hold in high esteem:

A wagon-maker, missionary, teacher, historian, poet, folklorist and editor. [...] He sought to explain and in certain respects defend Xhosa custom, a stance anathema to the missionaries, who were bent on its eradication. Gqoba lived his life as a Christian, but never compromised his pride in his Xhosa identity [...] Under Stewart's ea-

7 "The Ikhamanga flower (more commonly referred to as the strelitzia, crane, or bird or paradise flower) is one of the world's most recognisable flowers and is indigenous to the Eastern Cape. The Ikhamanga is the central motif of the Order of Ikhamanga and symbolises the unique beauty of the achievements of South Africans in the creative fields of arts, culture, literature, music, journalism and sport." http://ukznpress.bookslive.co.za/ blog/2017/03/29/ 
gle eye, Gqoba edited the Lovedale newspaper Isigidimi samaXosa (the messenger of the Xhosa people), to which he contrived to contribute to subversive poetry outspokenly critical of Western education, the European administration of black people and the social, economic and political discrimination suffered by colonized blacks. In his all too brief literary career, William Wellington Gqoba fashioned the figure of the Xhosa man of letters; unrivalled in his time in the generic range of his activities. (Opland, Kuse \& Maseko 2015: 3)

By looking at themselves as editors and translators, the authors have espoused Merolla, Ameka, \& Dorvlo's concept of researchers as griots which invites scholars to rethink their "positionality" (Hall, 1996). Positionality covers elements such as space, time, and institutional anchoring which shape researchers' subjectivity. The paper wishes for an ethically workable definition of archiving that can be applied to Africanist research in its wide scope. Moreover, the paper argues against silencing through archiving. In this sense, Derrida's (1994: 51) notion of "hauntology" - haunted ontology - is necessary for the process of delinking and insists on the fact that Africanist research should be more concerned with creating space for the ghost voices that are present in all texts.

\section{Two perspectives on African Studies}

To sum up, this position paper calls for the revival of the deleted "voices and voicings" (Harris 2015: 554) and pleads for the development of protective and pro-active steps to counteract the extraversion politics in archiving which calls Keita's (in Hountondji 2011: 93) note on the colonial research pact to mind. It consisted in "developing in dominated territories a feverish activity of gathering information destined for processing in the Metropolitan laboratories and research centres." Such protective and pro-active steps can take the shape of a framework which cannot escape the multidisciplinary paradigm as archiving collective memories involves disciplines such as anthropology, history, sociology, linguistics, literature, heritage cultural studies and law (copyrights, property rights and rights to access and accessibility at the age of digitization).

I would like to end the paper with a thought from the Beninese philosopher (Paulin Hountondji 2009: 6) which genuinely recaps an ideal direction in Africanist research and the theme of the $11^{\text {th }}$ ISOLA conference: Memory and Remembrance in Africa and the Diaspora. In his seminal paper titled Knowledge of Africa, Knowledge by Africans: Two perspectives on African Studies, he says the following,

Things should happen in Africa, therefore, and not always or exclusively outside Africa. Fairness to the black continent demands that all the knowledge accumulated throughout centuries on different aspects of its life be shared with the people who live there. It demands that adequate measures be taken to facilitate a lucid, a responsible appropriation by African of the knowledge available, the discussions and interrogations developed elsewhere. Such appropriation should go hand in hand with a critical re-appropriation of Africa's own endogenous knowledges, and, beyond, a critical appropriation of the very process of knowledge production and capitalization. 


\section{References}

Adichie, Chimamanda. "The Danger of a single Story”. http://ssw.unc.edu/files. Accessed 26 July 2017. Aggarwal, Kusum. Amadou Hampate Ba et L'africanisme. L'Harmattan,1990.

Bâ, Amadou Hampâté. 1973. The Fortunes of Wangrin. Translated by Aina Pavolini Taylor, Indiana University Press, 2000.

Bourdieu, Pierre. Les Règles de l'Art. Genèse et Structure du Champ Littéraire. Seuil, 1992.

Bourdieu, Pierre. The Sociology of Symbolic Power. Kluwer Acad. Publ, 2003.

Coetzee, Carli. Accented Futures. Language Activism and the Ending of Apartheid. Wits University Press, 2013.

Derrida, Jacques. 1993. Specters of Marx: The state of the debt, the work of mourning and the new international. Translated by Peggy Kamuf, Routledge, 1994.

Devy, Ganesh, Brown, Duncan "Orality and Literacy". A Concise Companion to Postcolonial Literature, edited by Shirley Chew and David Richards., Wiley-Blackwell, 2010, pp. 29-55.

Gqoba, William Wellington. Original author. Isizwe esinembali: Xhosa histories and poetry (1873-1888). Edited and translated by Opland, J, Kuse, W \& Maseko, P. University of KwaZulu-Natal Press, 2015.

Graeme, Councel. "The Syliphone archive: 8000 Guinean songs now on the internet / L'archive Syliphone: 8000 chansons Guinéennes sur Internet." Received from Apela mailing list, 26 Jan.2016.

Hamilton, Carolyn. Paper presented as part of the panel 'Interdisciplinary research: further afield', Prepostperform Colloquium, 20-22 February, 2010, Michaelis School of Fine Art, Cape Town.

Hall, Stuart. "Cultural identities and cinematic representation". Black British cultural studies: a reader, edited by Baker Houston et al. University of Chicago Press, 1996, pp. 201-222.

Harris, Verne. "Hauntology, Archiving and Banditry. An Engagement with Derrida and Zapiro." Critical Arts, vol. 29/supl, 2015, pp. 549-543, DOI:10.1080/02560046.2015.1102239

Houtondji, Paulin. "Knowledge of Africa, Knowledge by Africans: Two perspectives on African Studies". RCCS Annual Review [Online], 1 | 2009, Online since 01 September 2009, connection on 05 October 2016. URL: http://rccsar.revues.org/174 ; DOI : 10.4000/rccsar.174

Houtondji, Paulin. "Dialogue with Lansana Keita : Reflections on African Development." Philosophy and African Development : Theory and Practice, edited by Keita, Lansana. Codesria, 2011, pp. 86-96.

Jansen, Jan. "Copy Debts ? - Towards a Cultural Model for Researchers' Accountability in an Age of Web Democracy." Oral Tradition, vol. 27(2), 2012, pp. 351-362.

Jean-Marc Moura and Amadou Hampaté Bâ. "Textual Ownership in "L'étrange destin de Wangrin (The Fortunes of Wangrin)" by Amadou Hampaté Bâ." Research in African Literatures, vol. 37/1, 2006, pp. 91-99.

Jérôme, Roger. Préface. La question de l'auteur en littératures africaines, edited by Mazauric, Catherine \& Begenat-Neuschäfer. Peter Lang, 2015, pp. 9-16.

Kaschula, Russell. "Technauriture as a Platform to create an inclusive Environment for the Sharing of Research". Searching for Sharing. Heritage and Multimedia in Africa, edited by Merolla, Daniella \& Turin, Mark. Open Book Publishers, 2017, pp. 41-59.

Kros, Cynthia. "Rhodes Must Fall: archives and counter-archives". Critical Arts, 29/supl, 2017, pp. 150-165, DOI: $10.1080 / 02560046.2015 .1102270$

Lohnert, Beate (ed). Social Networks. Potentials and Constraints: Indications from South Africa. Verlag für Entwicklungspolitik, 2007.

Meizoz, Jérôme. Postures littéraires. Mises en scène modernes de l'auteur. Slatkine, 2007.

Merolla, Daniela, Ameka, Felix, in collaboration with Kofi Dorvlo. "Researchers as Griots? Reflections on Multimedia Fieldwork in West Africa". Oral Literature in the Digital Age: Archiving Orality and Connecting with Communities, edited by Turin, Mark et al. Open Books Publishers, 2013, pp. $65-90$. 
Mignolo, Walter. "Delinking: the rhetoric of modernity, the logic of coloniality and the grammar of De-coloniality". Globalization and the Decolonial Option, edited by Mignolo, Walter \& Escobar, Arturo. Routledge, 2010, pp. 303-368.

Nathan, David. "Access and Accessibility at ELAR, a social networking archive for endangered languages documentation". Oral Literature in the Digital Age: Archiving Orality and Connecting with Communities, edited by Turin, Mark et al. Open Books Publishers, 2013, pp. 21-40.

Nfah-Abbenyi, Juliana. "Bridging North and South. Notes Towards True Dialogue and Transformation". Canadian Woman Studies. An Introductory Reader, edited by Nuzhat, Amin et al. Inanna Publications and Education Inc, 1999, pp. 18-24.

Sanders, Mark. Complicities: the intellectual and apartheid. Duke University Press, 2002.

Vaux, Anthony. The Selfish Altruist. Relief Work in Famine and War. Earthscan, 2001.

\section{Websites}

http://britishlibrary.typepad.co.uk/endangeredarchives/2016/01/-archive-mbwaye-bokwango-cameroon. html\#sthash.1uVLrHBW.dpuf

https://www.youtube.com/watch?v=Yr2Vd0IrrRg

http://www.findanexpert.unimelb.edu.au/display/person 183008

http://www.radioafrica.com.au/Discographies/Syliphone.html

http://ukznpress.bookslive.co.za/blog/2017/03/29/jeff-opland-awarded-the-order-of-ikhamanga-silverfor-his-contribution-to-history-and-south-african-literature/ 